\title{
In search of the African voice in higher education: The language question
}

\author{
Russell H. Kaschula
}

NRF SARChI Chair in the Intellectualisation of African Languages, Multilingualism and Education, School of Languages, Rhodes University, Grahamstown

E-mail: r.kaschula@ru.ac.za

\begin{abstract}
This article seeks to understand what South African universities are doing by making use of language as a tool or as an enabling voice towards Africanisation and transformation with particular reference to Rhodes University, which serves as a case study. Although many universities now have language policies in place and are part of an enabling policy environment, when it comes to using language as part of transformation and asserting an African voice, there are still policy implementation challenges. It is argued in this article that implementation of policy, including university language policies, is now a key indicator for two levels of transformation; namely the more superficially visible or visual representation transformation, as well as deeper curriculum transformation through appropriate language usage. It is the latter form of transformation that largely eludes the contemporary South African university, whether these are historically black universities (HBUs) or historically white universities (HWUs). With the exception of a few best practices that are highlighted in this article, it is argued that transformation of the curriculum remains a long-term process, in the same way that language policy implementation is an ongoing process and requires commitment at all levels of university managerial and academic culture. The African voice in higher education remains an elusive one; though it is gaining ground, as evidenced by the recent removal of the Cecil John Rhodes Statue at the University of Cape Town. Furthermore, there is evidence of selected ongoing curriculum and pedagogic transformation, as presented in this article.
\end{abstract}

Keywords: African languages; voice; transformation and Africanisation; multilingualism; pedagogy and epistemology; university language policies; social cohesion

\section{Introduction}

The former Vice-Chancellor of Rhodes University, Dr Saleem Badat, raised a number of pertinent issues when delivering his welcoming address to delegates attending a seminar on "Africanisation and the Higher Education Sector" on 30 April 2014 in Grahamstown. Essentially, he raised five questions or points. Firstly, he asked whether a university can Africanise without transforming - in other words, what are we really talking about by using these terms? Secondly, how do we decolonise universities? This includes a de-gendering and 
de-masculinizing in building new academic cultures that embrace social inclusion and justice. Thirdly, one must debate the extent to which universities have critically analysed their traditions and cultures and engaged with pedagogic innovation at an epistemological level. Fourthly, university research and curricula need to engage with issues of transformation; lest universities simply remain in the mode of reproducing what already exists. Lastly, universities need to engage with producing students who show social accountability and who use their skills as instruments of the economy in an alternative manner to the neo-liberal globalisation epoch students who produce fresh ideas, rather than those who simply reproduce what they are taught. Essentially, this means finding an African voice in both the political and pedagogic sense of the word.

In my view, the above questions and points can be addressed by assessing the way in which language informs how we teach and what we teach across disciplines. How do we make use of English and African languages in university lecture halls? How does the indigenous knowledge that underpins African languages, accepting Horsthemke's (2014:11) argument that all knowledge is "knowledge per se", get reflected within curricula across disciplines, from the sciences to the humanities? It is these questions that this article attempts to answer. Universities have yet to seriously consider the language question as part of a deeper transformative voice. Raymond, Butt and Townsend (1992:57) posit that "[i]n a political sense, the notion of the teacher's voice addresses the right to speak and be represented. It can represent both the unique individual and collective voice...". Arguably, at the level of tertiary education in South Africa, there may be individual voices experimenting with, for example, multilingualism (du Toit 2016). However, the collective bi- or multilingual voice at tertiary level, and to a lesser extent at school level, does not yet exist, with the exception of schools and universities that have used Afrikaans as a medium of instruction, and more recently alongside English. This is confirmed by Anthonissen (2013:34), where she states that even if "...in decline in many public domains...", Afrikaans remains an important language of cognition alongside English. The term "multilingualism" has recently been defined by Stavans and Hoffman (2015:2), where they state that "...multilingualism is taken in its literal meaning: the presence of more than two languages either in individuals or in society". Another way of viewing multilingualism is that it is the existence of or the ability to use more than one language; and can be found at individual, societal, institutional, national-territorial, or sub-regional/international levels. The latter view is used as a position of departure in this article.

Building on this notion of multilingualism, South African universities should be thinking of intellectualising selected African languages to be used as media of instruction where the majority of students speak such a language and are proficient in it as a mother tongue. The term "intellectualisation" is a contentious one, but in this instance, it is taken to mean the entrenchment of both corpus and status language planning; in other words, developing linguistic repertoires in a language as well as academic visibility. The notion of the intellectualisation of languages is the applied sociolinguistic equivalent of the political agenda regarding the empowerment of languages. It targets the usability and actual use of any language in all semantic and pragmatic domains; particularly in education. This term implies that African languages already have intellectual content and form to draw on in furthering this intellectualisation process.

The intellectualisation process at universities should be done in the interests of better cognition and conceptual understanding, which are the core business of any university, whether located 
in China and teaching in Chinese, or in Germany and teaching in German. Busch, Busch and Press (2014:311) refer to Alexander's notion of "intellectualisation" of African languages as a way forward. This additive, mother-tongue-based language of instruction policy has already been proposed in policy documents at the University of KwaZulu-Natal, which is forging ahead with its compulsory isiZulu language-learning policy; thereby bringing the student back to the centre of the debate of what role the university actually serves in South African society, and what type of student should be graduated. What stops a history class (dealing with Eastern Cape history), for example, from being taught and examined in isiXhosa at Walter Sisulu University, where the majority of students and the lecturer are isiXhosa-speaking? The answer is simple. It is not the lack of isiXhosa vocabulary, but rather the neo-colonial, silenced or oppressed voice and attitudes of students who embrace the hegemony of English no matter what the intellectual cost to themselves, and lecturers as well as a minority of students (often monolingual) who do not wish to experiment with multilingualism in the sense of embracing language as a resource. They represent what could be referred to as a silent and often distorted monolingual English voice in a naturally noisy multilingual African environment. They rather resort to seeing language or multilingualism as a problem, and therefore as something to be avoided in the lecture halls and tutorials (Ruíz 1984). According to Wolff (2013:12), these negative attitudes towards multilingualism and multiculturalism "...have meanwhile turned into self-fulfilling prophecies which are prohibitive to the empowering use of African languages in high and prestigious domains... formal - and in particular higher - education, science and technology".

One needs to draw a distinction between the language of learning and teaching (LoLT), i.e. the language of instruction at South African universities, at the moment English, and how languages other than English can be used in an empowering and transformative way; in other words, to be seen as a resource rather than as an impediment. Ruíz's (1984) three orientations to language planning - namely language as a problem, language as a right, and language as a resource - constitute a theoretical framework that university language planners need to engage with. Orientation refers to "a complex of dispositions toward language and its role, and toward languages and their role in society" (Ruíz 1984:16). The crucial argument is that the significant role of language planners is to keep these language orientations overt. The role of language planners, whether they be at universities or not, is to confirm whether these orientations have been accommodated in the existing policies, and also to advocate them in newly-established policies (Ruíz 1984:16).

\section{What is the language question at South African universities?}

Alexander (2005:30) sums up the challenge facing South African universities as follows:

The basic idea is that a university or group of universities would be given the task of developing specific languages such as isiZulu, or isiXhosa, or Sesotho, or Setswana and over a period of 10 to 15 years... a step-by-step development and implementation plan should be formulated...such that...it will be clear when they will be able to be used as languages of tuition in specific disciplines. The decision, however, about when to begin using the languages for specific functions will be the prerogative of the relevant institutional community.

Each university must then formulate its own approach to change and transformation, language arguably being the core voice of such transformation. Makgoba and Seepe (2004:19) are of the 
opinion that Africanisation and transformation will "give us a new approach in knowledge seeking". However, change cannot be simply imposed from outside. It needs to come from within, and there must be buy-in from authorities and all stakeholders, i.e. management as well as academic and support staff, as part of what will later be referred to as "meaningful engagement" (Webb 2006). Universities and specifically curricula should no longer be defined by imperialist and colonialist ideology, but by African values and philosophy, an African voice underpinned by African languages and indigenous knowledge systems (IKS) as part of all "knowledge per se" (Horsthemke 2014).

Makgoba and Seepe (2004:18) initiated this debate on transformation as part of grappling "... with the meanings, the implications and consequences of what an African university is and ought to be". The first crucial step towards this is to create language equality and to intellectualise African languages (see also Wildsmith-Cromarty 2010). It is language that holds the key to transformation, as language is the voice and transmitter of all knowledge. The challenge is to establish what languages are to be used and heard, as well as in what contexts within higher education. A simple example would be the following: even though one may be teaching a course in English-language linguistics, when dealing with the concept of a language, a variety, or a dialect, there is no reason that students cannot relate this knowledge to their own mother tongues; for example isiXhosa, where a number of dialects can be found.

A further challenge in the development of African languages in higher education is at the policy level; what Elbaz (1991) refers to as "political usage" of voice. While admirable policies exist, which at a glance should ensure development of African languages and promotion of multilingualism, these policies often lack a plan for implementation, as well as directives on who should lead or drive implementation (at both national and institutional level). The other factor related to implementation is monitoring. The Language Policy on Higher Education (LPHE) and the Report on the Development of Indigenous Languages as Mediums of Instruction in Higher Education, for example, state clearly what needs to be done by institutions in promoting the development of African languages. However, there is little monitoring of the extent of compliance with the provisions of policy. The simple example is that of the formulation of institutional policy and the institutions' submission to the Ministry of Education of their five-year plan regarding the development of African languages as media of instruction. The LPHE (Department of Education 2002) requires that Higher Education Institutions (HEIs) formulate their policy with an implementation plan and publish it. The LPHE also stipulates that every five years, HEIs should provide the Ministry of Education with a report that details the extent of the implementation of their plans. While 19 of the 25 HEIs have published their policies, very few have provided the Ministry with a report on the progress of policy implementation. The essence of the argument here, though, is that the policy could be sufficient, but lacks strategies and other means to monitor compliance; thereby maintaining the status quo of the silence associated with the African voice at our universities.

It has already been alluded to above that South Africa is arguably a "policy super highway". As indicated, university language policies have been created but not policed. Kotze (2014:15) suggests that a favourable policy landscape has now emerged. There are however very few reststops along the "policy super highway" to actually engage with policies and to assess their effectiveness and appropriateness. For every policy, there should be an implementation plan, and a way of checking the success of the policy's implementation. The recent Higher Education Ministerial Committee (2013) chaired by Professor Pitika Ntuli, which looked at the use of 
African languages across campuses and assessed policy implementation, was arguably an attempt to remedy this and to hold universities accountable.

We know that national policy, particularly the Constitution of 1996, is burdened with limitation clauses such as "where possible", "where practicable", and so on. Policy at institutional level seems to take its cue from national policy and, as such, institutions seem to be able to escape some of their responsibilities towards the use and development of African languages. For example, even though Rhodes has worked hard to implement its language policy, which advocates the use of isiXhosa in academic spheres, the revised 2014 Rhodes University Language Policy contains numerous loopholes in favour of the university administration. It would seem that the reason for this is to cover the university in case of any legal court cases that may emanate from lack of implementation. On closer examination, all language policies, whether they be university policies or otherwise, seem to follow the same approach. The complexities associated with such implementation within the work environment are explicated by e.g. Anthonissen and Kaschula (1995) as well as Anthonissen (2010) in relation to medical, legal, and business settings.

There seems to be a disjuncture then between the law, namely the legislation, and the linguistic component, namely the content of the policy, which results in the actual language implementation failures. The question remains as to where the actual problem is located: Is it, for example, the policies and legislation that do not give effect to the constitutional mandate; or is it the implementation phase that is problematic? There are many policies and much legislation that deal only with languages, or that make reference to and include a section on languages. This can be viewed as an advantage. However, the number of policies does not illustrate the success in the implementation stages. It rather illustrates a failure within the implementation stage, where policies seem to overlap and carry out the same mandate. A contributing missing link is the lack of all-encompassing legislation. The Use of Offical Languages Act of 2012 (Act No 12) attempts to provide an all-encompassing piece of legislation; though it is not without its complications. Section (4)(1) requires all national departments, public entities, and public enterprises to adopt language policies within 18 months of commencement of the Act. Arguably, this will again contribute further to the "policy super highway" syndrome if proper implementation plans do not accompany such policies. Through assessment, it is clear that there is a failure to implement at our universities for a number of reasons, and that this effectively halts transformation and Africanisation. A solution that is legally sound and linguistically equipped to resolve issues and successfully implement language legislation and policies is required. It is suggested that this is the concept of 'meaningful engagement', as illustrated in the Rhodes Language Policy example in a section that follows (see Kaschula and Docrat 2014). Attempting to find a tool that has the potential to reverse the status quo and implement language policies and legislation successfully is now more important than ever in order to give voice to this aspect of transformation.

Meaningful engagement is a tool that has been successful where people were facing eviction from their places of residence for various reasons. Courts of law suggested that landowners "meaningfully engage" in order to find solutions. With the development of an original concept by the protectors and enforcers of the Constitution, i.e. the constitutional justices, the concept of 'meaningful engagement' was introduced, developed, and successfully applied within a socioeconomic rights sphere of eviction. As stated above, language and law are inseparable. Thus, the concept of 'meaningful engagement' will allow for a legal concept to be utilised that 
has the potential to successfully implement language policies and legislation. There has been a constant call for engagement to occur, more recently by the late Neville Alexander (2013), who unequivocally stated: "My sincere wish is that readers will consider these thoughts, take a step back and try to get a perspective on what has actually been happening since 1990, when the new South Africa began. Even more optimistically, I hope that such a rethink will inspire the reader to want to find a point of engagement". It is really to re-engage once more with policy in a critical, consultative and robust manner. The tool of meaningful engagement with all stakeholders is proposed in the quest for successful language policy implementation and transformation not only within the country more generally, but within context-driven environments where language policies have been and are being drafted to assist with transformation; for example universities, banks, the schooling system, and within the broader public and private sectors. In other words, universities in particular need to meaningfully engage within their respective contexts in order to come up with language policies and implementation plans that have buy-in from all sectors of the university, and whereby the African voice is then pedagogically asserted through appropriate curriculum change.

\section{The role of the university in voicing social needs through language usage}

What is now required at South African universities is an intersection of managerial staff, support staff, and the student and academic fraternity in a meaningfully engaged way, and not in a way that fosters opposition. Arguably, this will create mindfulness and inclusivity as part of a wider transformation of university culture that addresses the notion of previously silenced or marginalised voices (Langer 1989:69; Ting-Toomey 1999:3). This can be achieved by increasing the visibility of other languages used on campuses, while still supporting English as an LoLT. It is then about developing and promoting languages in order to create an appropriate multilingual and effective cognitive and intellectual environment. In earlier interviews with the late Nadine Gordimer, she rightly refers to English as an "adjunct African language", though a fully-developed language. It would therefore be important to emphasize the intellectualisation of African languages alongside English and to some extent Afrikaans. Arguably, as this article suggests, there is presently a renegotiation of new and old identities; especially at HWUs, English- and Afrikaans-medium institutions such as the University of Cape Town (UCT), Rhodes, and the University of KwaZulu-Natal (UKZN). The "Rhodes Must Fall" debate of 2015 and the removal of the Rhodes Statue at UCT, as well as the more recent "Fees Must Fall" protests of 2016, are examples of this renegotiation and asserting of contemporary voices. In this context, it is important to create "familiarity" rather than "identity vulnerability". It is about "...negotiating shared meanings in an interactive situation" (Ting-Toomey 1999:1-2). Even if one considers a small university such as Rhodes, more than 25 languages are represented and spoken on campus; with more than 1,600 of the 7,800 students speaking isiXhosa as a mother tongue.

In regard to this diversification of the student body, strategies for increased "social penetration" are also required as part of the transformation process (Chen 2003:225); i.e. designing appropriate curricula particularly in African languages, and making the languages visible through visual representation such as signage and multilingual graduation ceremonies. Deeper curriculum change and multilingual courses can arguably create meaningful interaction, despite perceived and stereotyped cultural differences. Intercultural communication and increased social cohesion is then inevitable in this context, thereby entrenching the African voice and identity. Therefore, South African universities must play a significant role in implementing 
multilingualism in the educational milieu in order to assist with the transformation and Africanisation of universities (Alexander 2002; Kaschula and Maseko 2009; Maseko 2014).

Part of this transformation deals with the notion of identity negotiation. The challenge at most South African universities is to negotiate an identity of belonging for students. Language and culture are important in this process, and acknowledgement thereof can create an environment conducive to inclusivity rather than exclusivity. Furthermore, an individual's self-identification through language opens up interaction with other cultures, thereby deepening a unified sense of voice rather than voiceless silence and cultural alienation. Developing mother-tongue and second-language vocation-specific courses is integral to fostering this sense of acceptance and inclusion (Maseko 2008; 2014). This will be discussed in more detail later in this article.

It is equally important to develop material in African languages to support the LoLT, which in most HEIs is English (Wolff 2002, 2013; Dalvit, Murray and Terzoli 2009; Sam 2010; Gambushe 2014; Mawonga 2014). The way in which we use and talk about languages at universities will influence campus "culture". Language is the vehicle of culture (Lanham 1980:11). In this regard, African languages are important in affirming an identity that has been undermined by dominant Eurocentric societal and institutional systems which tend to acknowledge and support the minority rather than the majority. In developing university programmes that promote multilingualism (as already suggested by Minister Nzimande as early as 2011 and quoted in Turner 2011), we should be informed by intercultural theorists such as Ting-Toomey (1999), Gudykunst (2003), and Collier (1997). Ting-Toomey talks of "identity vulnerability" where we communicate with unfamiliar people. Universities need then to create "identity security" through multilingual/multicultural programmes that serve to foster transformation. This is presently being done at UKZN with the introduction of isiZulu; and at Rhodes University with the compulsory teaching and learning of isiXhosa (mother-tongue and second-language) for Journalism.

Both Ting-Toomey and McLaren (1998:16) highlight the fact that culture is a changing human phenomenon that should be respected, both in terms of one's own culture and the values of others. Gudykunst (2003:163) points out that "[i]ntercultural communication...is conceptualised as communication between people from different...social classes, and interracial/interethnic communication...". On the one hand, culture is like an iceberg: the deeper layers - for example, traditions, beliefs, and values - are hidden from our view; we only see and hear the uppermost layers of cultural artefacts, fashion, trends, and pop music. On the other hand, culture is dynamic and changes with the people within the system. This dynamism can be reflected in the cultural artefact; for example, Western and African healing systems in pharmacy or medical courses. Shared features of South African "culture" seem to emerge only at the uppermost levels, and universities need to engage with this in creative ways in order to create a deeper meaning of social cohesion and a unified voice. Ting-Toomey (1999:3) states that "...the achievement of effective intercultural communication is dependent on people's ability to manage differences flexibly and mindfully". University courses should be underpinned by an ethos of respect for the self and others. They are central to university transformation; representing a deeper, more difficult level of transformation than e.g. visible multilingual signage or visual representation, though these are also important (Kaschula et al. 2009). It is these two facets of transformation that this article attempts to grapple with. 


\section{Linguistic best practices at our universities as part of broader transformation}

Most universities now have a language policy, but as already discussed, few are accompanied by successful implementation plans. According to Maseko (2008:70), "[i]ndigenous African languages in South African tertiary institutions, historically, have never been used in various teaching acts, across disciplines, for example, as mediums of instruction, or as languages of assessment". This is so even though there is clear evidence that their use to support the LoLT can improve cognition and social cohesion (Wolff 2002; Dalvit et al. 2009; Maseko 2011; Gambushe 2014). Although many of the 25 South African universities have a language policy that is favourable to the promotion of African languages, only a handful have implementation plans and are actively promoting African languages in their teaching acts; i.e., finding an African voice. An example of best practice related to the integration of language teaching within the sciences would be that of UCT, where since 2004 no medical student can graduate without passing vocation-specific courses in isiXhosa and Afrikaans. These languages are taught and assessed through a process of on-site clinical examinations (OSCEs), where the student is evaluated by both linguists and clinical skills experts when examining a patient. The objective is to evaluate how well the candidate examines the patient while using the patient's mother tongue; in this case isiXhosa, Afrikaans, or English (Kaschula 2013).

At UCT, there is also the innovative work of the relatively recently-formed Centre for African Language Diversity (CALDi), which researches Khoi and San languages; as well as the Centre for Higher Education (CHED), the latter focusing particularly on terminology development and the creation of isiXhosa glossaries to aid cognition and transfer to English (Madiba 2014). The University of KwaZulu-Natal also has innovative language-learning programmes in isiZulu for nursing and psychology, and recently made the study of isiZulu compulsory at the secondlanguage level (Ngcobo 2014). The University of Venda offers a Bachelor of Arts (BA) in IKS; and has introduced other African languages, including minority languages such as isiNdebele. A further example of best practice would be the isiXhosa glossaries that have been developed at the University of Stellenbosch as well as at the University of South Africa; for example in psychology. The Nelson Mandela Metropolitan University offers short courses in translation studies, and has opened a Translation and Interpretation Office as part of the Department of Applied Language Studies in the Faculty of Arts. The University of North-West has implemented a process of simultaneous translation within the lecturing system, and text editing programmes for African languages which are ongoing and contribute to concept formation and terminology development.

One of the proven initiatives is that being pursued at the University of Limpopo, which offers a BA degree in multilingualism (BA Contemporary English and Multilingual Studies (BA CEMS)), where some subjects are completed in Sepedi (Sesotho sa Leboa) and others in English (Ramani 2011). This is a model that universities need to explore further, and the number of students enrolling for this course has grown exponentially. What makes this approach unique is that it is a linguistically mutually inclusive approach that embraces both English and an African language. It is perhaps the "most complete response" to the 2002/3 Department of Education policy. A similar model has been approved for implementation by the Institutional Planning Committee at Rhodes, where a bilingual isiXhosa-English Foundation Phase Bachelor of Education (B.Ed) programme is to be piloted in 2015 in the hope of graduating students who have a better understanding of the concept of bilingualism and its educational value. There are also initiatives at Rhodes to aid cognition, understanding, and transfer to English by using the 
mother tongue in cell biology and politics. In these subjects, MA research has contributed to terminology creation and to a broadening of the African voice within disciplines where teaching and learning previously took place only through the medium of English.

There are also individual courses at some institutions where mother-tongue-based bilingual education (MTBBE) models are followed; e.g. the Ulwimi Noluntu (Language and Society) course for isiXhosa 1 at Rhodes University. However, there has been limited experimentation across universities with this approach, aside from the Limpopo model outlined above that speaks to MTBBE. Mother-tongue and second-language isiXhosa students at Rhodes are taught in the same sociolinguistics class. Everything that is said in English is repeated in isiXhosa. Students are allowed to ask questions in either language, and are answered in that language with a brief explanation given in the alternate language. This approach has proven to be very empowering, particularly for the mother-tongue isiXhosa students who tend to ask many more questions when permitted to do so in isiXhosa, thereby showing greater conceptual engagement. The above also clearly speaks to deeper cognitive development through the transformation of curricula where students write assignments and tests in their respective mother tongues.

\section{Rhodes University: A case study}

In a recent study, Stein (2014:3) suggests that while much has been achieved in terms of transformation of the student body at Rhodes, these initiatives, "...while commendable, have not gone far enough in terms of tackling the problem of Rhodes' "racialized identity". This can be said of most HWUs. In a similar vein, Mkhize (2005:119) describes the institution as a "... white colonial vestige in a predominantly black South Africa...", thereby bringing to the fore the colonial legacy and culture that still persists at the institution. Indeed, once again, the ongoing role of language usage in changing this "voiceless" legacy and enabling transformation and Africanisation is crucial, as shown below.

What follows is a brief analysis of the teaching and learning of isiXhosa at Rhodes University, arguably a success story; as well as the creation and implementation of a language policy at the university as part of greater transformation. The purpose of this case study is to assess the extent of meaningful engagement with regard to language issues and to provide a possible model for implementation; thereby contributing to ongoing transformation (Docrat and Kaschula 2015). Through engagement with management and recognising a need from the student body, isiXhosa mother-tongue courses were introduced in 2008. It is indeed almost inconceivable that a university in the heartland of amaXhosa speakers would not have offered isiXhosa at the mother-tongue level as part of the Africanisation of the university; where isiXhosa mothertongue students can learn about and in the language, creating "voice" where there was previously academic silence (Obanya 2004). Previously, students could only learn isiXhosa as a second or additional language. Today, there are 500 students studying isiXhosa at both mother-tongue and second-language levels at this university, from first year through to third year, Honours, MA, and PhD levels; as well as the vocation-specific courses discussed below. The Humanities Faculty Board has also accepted that postgraduate theses can now be written in a language other than English. Indeed, language has become a visible marker of Africanisation in what was arguably one of the most Eurocentric universities in South Africa, as reflected even in the controversial name "Rhodes University". As part of this transformation, vocation-specific courses have been developed in journalism, law, education, and pharmacy; 
with the isiXhosa course that forms part of journalism being compulsory at either the mothertongue or the second-language level. In other words, in the same way that a UCT student cannot graduate with a medical degree without passing isiXhosa and Afrikaans, journalism students at Rhodes must pass the required level of isiXhosa. When it comes to the teaching of African languages as second languages, generic first additional language or second-language courses do have their place. However, there needs to be a more integrated social approach to the teaching of these languages as part of transforming university curricula and culture, creating the "mindfulness" discussed earlier in this article. Furthermore, the development of vocationspecific courses is vital at this time in South Africa's socio-political history. There remains little evidence of a normalised, integrated, transformed, multilingual society, at least from a linguistic point of view. Instead, what exists now is a "linguistic fault line" which divides the "haves" and the "have-nots" into a three-tier economic system, based on those citizens who are communicatively competent in English, those who have a partial knowledge of the language, and those who speak no English at all (Alexander 2002). It could be argued that the growth in numbers and diversification of isiXhosa courses came about at Rhodes through a process of meaningful engagement with students, management, and experts in the respective fields such as pharmacy, as well as with practitioners on the ground. Interviews with practitioners and observations in loco influenced the design and content of the respective curricula.

The above developments are informed by the university language policy, which was accepted by the Senate and the University Council in 2005 and revised in 2014. As part of a meaningful engagement exercise, the university approved the formation of the University Language Committee in 2011. This committee is made up of representatives from across the university community, from support staff to students, professors, and deans of faculties. The main function of this committee is to oversee the implementation of multilingualism on campus in a meaningfully engaged manner, to organise annual multilingualism awareness events, as well as to revise the University Language Policy every three years (for further information, see Docrat and Kaschula 2015). The Rhodes Language Committee is based on the model followed at UCT.

The Rhodes language policy was revised in 2013, and the revisions were approved by the Senate and Council in 2014. The policy is trilingual and available in isiXhosa, English and Afrikaans. This policy revision involved an extensive attempt at meaningful engagement. A matrix containing a questionnaire was sent out to the entire university community, including the student council, all heads of departments, units, institutes, and trade unions. This was to assess the state of multilingualism on campus, and to assess further what the university community wished to achieve with regard to the implementation of the language policy and multilingualism. The responses to this questionnaire were collated and analysed by a subcommittee of the Language Committee. The sub-committee then reworked the policy in line with the collated comments and suggestions. The revised document was tabled a number of times to the Language Committee. Once accepted, it was forwarded to the Equity and Institutional Culture Committee, where it was again reworked by a sub-committee set up by the Vice-Chancellor, which included members of the Language Committee. It was then submitted for final approval from the Senate in May 2014 and duly accepted. The above data and analysis of process are included here as an example of an attempt at a meaningful engagement exercise to encourage transformation and Africanisation in a transparent and meaningful way. In this regard, the late Neville Alexander, in his extensive body of works ranging from the inception of a democratic South Africa to his last publication entitled Thoughts on the New South Africa 
(2013), points out that there has been no one policy or legislation that has addressed both the constitutional language provisions and been successfully implemented.

Furthermore, at Rhodes and various institutions of higher learning, the intellectualisation of African languages is seen as part of transformation at South African universities. At certain universities, this is being facilitated through centres; for example, the CHED at UCT and the Fundani Centre for Higher Education Development at the Cape Peninsula University of Technology. The University of Johannesburg has a Language Unit that fulfils this purpose. At other universities, it is being spearheaded by departments of African languages; for example at the University of Venda and the University of South Africa.

More recently, this intellectualisation is being facilitated by a Department of Higher Education and Training Catalytic Project in African language concept formation run by the Centre for Education Policy Development (CEPD) and hosted by Rhodes University. This project is working across universities, provinces, and languages. A further example is the National Research Foundation (NRF) Chair in the Intellectualisation of African Languages, Multilingualism and Education, hosted at Rhodes University and working in six areas of intellectualisation; namely policy formation, applied language studies, lexicography, terminology development, theoretical linguistics, and literature. The Chair facilitates national research in linguistic theory, applied language studies, and literary studies. This will hopefully lead the way for universities to see intellectualisation in process, and to see how it can assist with deeper transformation at South African universities.

\section{Comparative intellectual views on the African voice in higher education}

One of the central themes presented at the Rhodes University transformation seminar referred to at the beginning of this article was that knowledge has roots from where it emanates, and that ordinarily the voice that transmits knowledge comes from within. It moves from the local to the global. Nkoane (2014:3) clearly states that "Africanisation is a platform that holds African experiences as sources for the construction of forms of knowledge". This implies that South African universities should embrace an African ethos, including using African languages to inform learning and teaching. This implies interdisciplinary approaches linked to African values, cultures, and languages.

In a similar argument, Steyn (2014:2) concludes that "racialized identities impact transformation - institutional culture, where our institutions remain white-oriented; the 'epistemologies of ignorance' which characterize white-dominated knowledge construction...where our thinking remains caught up in a racialized binary". Arguably, if we are to transform universities today, then the "racialized binary" can include all those who aspire to knowledge production as understood in a certain Western way, whether they are black or white. Again, the language issue comes into play, as intellectual domination is linked to English hegemony in the case of the African continent, and in particular in relation to southern Africa. It is then about expanding intellectual repertoires by using local knowledge as a point of reference, and thereby encouraging transformation once again at a deeper level.

Le Grange (2014:5) calls for socially-distributed knowledge through service courses to be part of wider transformation. He asks the pertinent question: "What knowledge is of most worth to South African university students located on the African continent and part of a global society?" 
He argues further that the downside of university autonomy is that "decolonization of the curricula" has often been left unaddressed. Again, this speaks to the necessity for each discipline to interrogate what knowledge really amounts to in our context, and highlights that this process may need to be driven collectively by university managers as well as the academic fraternity. In terms of research, Pityana (2014:12) emphasises the need to write and publish in African languages, and to create a "multi-ethnic curriculum". Similarly, Ntuli (2014:3) argues for "counter hegemonic discourses" and a "re-Africanisation" rather than Africanisation, allowing culture and language to become central in what we do at universities. Steyn (2014:6) summarises this as follows: "The central dynamic that needs to be addressed is the power imbalances that hold the normative in place, and prevents genuine dialogue between different traditions, allowing something new to emerge in which there is mutual influence, intellectual and cultural". Arguably, if one learns an African language as a second language, or one learns in one's mother tongue through the use of an intellectualised meta-African language, or one makes use of the mother-tongue meta-language to "translanguage" to English, this directly challenges the concept of holding the "normative in place", and it embraces transformation and Africanisation at its deepest level, that of cognition and thought-creation.

\section{Conclusion}

What is suggested by the argument presented in this article is that the missing link in the Africanisation and transformation debate is the silent voice of language. Elbaz (1991:10) states that voice "...is always used against the background of a previous silence, and it is a political usage as well as an epistemological one". Language policy then relates to political usage, whereas cognition relates to epistemic access. It is language that underpins indigenous knowledge, knowledge formation, African identity, and culture. If African thought and knowledge has nothing to offer, then why do we have to fight in international courts to keep the names and knowledge associated with e.g. the Hoodia plant, Rooibos tea, the Lion King, and healing systems more generally? It is then how we choose to use our African knowledge and languages, and for what purposes we use them alongside English and Afrikaans on our campuses, that can serve as a tool in transformation and creating voice. Whether we teach an isiXhosa vocation-specific course for pharmacy students who are second-language speakers, or whether we offer history courses by using multilingual texts in translation for analysis (du Toit 2016), or whether we choose to offer isiZulu glossaries for better cognition and transfer to English in cell biology or psychology, this deeper curriculum transformation remains at the core of the Africanisation of South African universities and of re-connecting with the silent voice within us.

\section{Note}

The financial assistance of the NRF towards this research is hereby acknowledged. Opinions expressed and conclusions arrived at are those of the author and are not necessarily to be attributed to the NRF.

\section{References}

Alexander, N. 2002. An ordinary country. Issues in the transition from apartheid to democracy in South Africa. Pietermaritzburg: University of Natal Press. 
Alexander, N. (ed.) 2005. The intellectualisation of African languages. Cape Town: PRAESA/University of Cape Town.

Alexander, N. 2013. Thoughts on the new South Africa. Johannesburg: Jacana Media.

Anthonissen, C. and R.H. Kaschula. 1995. Communicating across cultures in South Africa. Toward a critical language awareness. Johannesburg: Wits Press/Hodder \& Stoughton.

Anthonissen, C. 2010. Managing linguistic diversity in a South African HIV/AIDS day clinic. In B. Meyer and B. Apfelbaum (eds.) Multilingualism at work: From policies to practices in public, medical and business settings. Amsterdam: John Benjamins. pp.71-96.

Anthonissen, C. 2013. 'With English the world is more open to you' - language shift as marker of social transformation. English Today 29(1): 28-35.

Busch, B., L. Busch and K. Press. (eds.) 2014. Interviews with Neville Alexander. The power of languages against the language of power. Pietermaritzburg: University of KwaZulu-Natal Press.

Chen, L. 2003. Communication in intercultural relationships. In W. Gudykunst (ed.) Crosscultural and intercultural communication. London: Thousand Oaks, New Delhi, Sage Publications. pp. 225-252.

Collier, M.J. 1997. Cultural identity and intercultural communication. In L. Samovar and R. Porter (eds.) Intercultural communication. A reader. San Francisco: Wadsworth. pp. 36-44.

Constitution of the Republic of South Africa, Act 108 of 1996.

Dalvit, L., S. Murray and A. Terzoli. 2009. Deconstructing language myths, which languages of learning and teaching in South Africa. Journal of Education 46: 33-56.

Department of Education. 2002. Language policy for higher education. Pretoria: Government Printers.

Department of Education. 2003. Development of indigenous languages as mediums of instruction in higher education. Report compiled by the Ministerial Committee appointed by the Ministry of Education. Pretoria: Government Printers.

Docrat, Z. and R.H Kaschula. 2015. Meaningful engagement: Towards a language rights paradigm for effective language policy implementation. South African Journal of African Languages 35(1): 1-9.

Du Toit, M. 2016. A multilingual approach to teaching South African history. In R. Kaschula and E. Wolff. (eds.) Multilingual education for Africa: Concepts and practices. Pretoria: Unisa Press. London and New York: Routledge.

Elbaz, F. 1991. Research in teachers' knowledge: The evolution of a discourse. Journal of Curriculum Studies 23(1): 28-35. 
Gambushe, W. 2014. Implementation of multilingualism in South African higher education: Exploring the use of isiXhosa in teaching and learning at Rhodes University. MA thesis. Grahamstown: Rhodes University.

Gudykunst, W. 2003. Issues in cross-cultural communication research. In W. Gudykunst (ed.) Cross-cultural and intercultural communication. London, Thousand Oaks, New Delhi: Sage Publications. pp. 149-161.

Horsthemke, K. 2014. Africanisation and the transformation of the higher education curriculum in South Africa: Limits and possibilities. Paper presented at the Rhodes University Seminar on Africanisation and Higher Education. Grahamstown.

Kaschula, R.H. and P. Maseko. 2009. Vocational language learning and teaching at a South African university, preparing professionals for multilingual contexts. Stellenbosch Papers in Linguistics PLUS 38: 130-142.

Kaschula, R.H., P. Maseko, L. Dalvit, T. Mapi, L. Nelani, B. Nosilela and M. Sam. 2009. An intercultural approach to implementing multilingualism at Rhodes University, South Africa. Stellenbosch Papers in Linguistics PLUS 39: 45-61.

Kaschula, R.H. 2013. Challenging the forked tongue of multilingualism: Scholarship in African languages in South African universities. In C. Altmayer and E. Wolff (eds.) Africa: Challenges of multilingualism. Frankfurt: Peter Lang. pp. 203-221.

Kaschula, R.H. and Z. Docrat. 2014. Meaningful engagement: Towards a coherent language rights paradigm for effective language policy implementation in South Africa. Conference paper read at the $18^{\text {th }}$ African Languages Association of Southern Africa Conference. Mthatha: Walter Sisulu University.

Kotze, E. 2014. The emergence of a favourable policy landscape. In L. Hibbert and C.van der Walt (eds.) Multilingual universities in South Africa. Reflecting society in higher education. Bristol, Buffalo, Toronto: Multilingual Matters. pp. 15-27.

Lanham, L. 1980. Language and thought, exploring the implications of the Whorfian hypothesis in social science. Unpublished inaugural address. Grahamstown: Rhodes University.

Langer, E. 1989. Mindfulness. Reading, MA: Addison-Wesley.

Le Grange, L. 2014. Currere's active force and the Africanisation of the university curriculum. Paper presented at the Rhodes University Seminar on Africanisation and Higher Education. Grahamstown.

Madiba, M. 2014. Promoting concept literacy through multilingual glossaries: A translanguaging approach. In L. Hibbert and C. van der Walt (eds.) Multilingual universities in South Africa. Reflecting society in higher education. Bristol, Buffalo, Toronto: Multilingual Matters. pp. 68-87. 
Makgoba, M. and S. Seepe. 2004. Knowledge and identity: An African vision of higher education transformation. In S. Seepe (ed.) Towards an African identity of higher education. Pretoria: Vista University \& Skotaville Media. pp. 13-58.

Maseko, P. 2008. Vocational language learning and how it relates to language policy issues. MA thesis. Grahamstown: Rhodes University.

Maseko, P. 2011. Intellectualisation of African Languages with particular reference to isiXhosa. Doctoral dissertation. Grahamstown: Rhodes University.

Maseko, P. 2014. Multilingualism at work in South African higher education: From policy to practice. In L. Hibbert and C. van der Walt (eds.) Multilingual universities in South Africa. Reflecting society in higher education. Bristol, Buffalo, Toronto: Multilingual Matters. pp. 2845.

Mawonga, S. 2014. Bilingual teaching practices in South African higher education: Making a case for terminology planning. MA thesis. Grahamstown: Rhodes University.

McLaren, M. 1998. Interpreting cultural difference. The challenge of intercultural communication. Dereham: Peter Francis Publications.

Mkhize, N. 2005. Am I just a white-washed black woman? What transformation means to a privileged young black woman. Agenda 19(65): 116-122.

Ngcobo, S. 2014. Dual language instruction: Its impact on attitudes towards the role of African languages in education. In L. Hibbert and C. van der Walt (eds.) Multilingual universities in South Africa. Reflecting society in higher education. Bristol, Buffalo, Toronto: Multilingual Matters. pp. 123-144.

Nkoane, M. 2014. Is the notion of Africanisation an enabling premise for the transformation of South Africa universities in the $21^{\text {st }}$ century? Paper presented at the Rhodes University Seminar on the Africanisation of Higher Education. Grahamstown.

Ntuli, P. 2014. Africanisation: The basis of self-transformation? Paper presented at the Rhodes University Seminar on the Africanisation of Higher Education. Grahamstown.

Obanya, P. 2004. Learning in, with and from the first language. PRAESA Occasional Paper, No. 19, Cape Town: PRAESA.

Pityana, B. 2014. Research and the African university. Paper presented at the Rhodes University Seminar on the Africanisation of Higher Education. Grahamstown.

Ramani, E. 2011. BEEP Bulletin. Alice: Fort Hare.

Raymond, D., R. Butt and D. Townsend. 1992. Contexts for teacher development: Insights from teachers' stories. In A. Hargreaves and M. Fullan (eds.) Understanding teacher development. New York: Teachers College Press. pp. 143-162. 
Rhodes University. 2014. Language policy. Grahamstown: Rhodes University.

Ruíz, R. 1984. Orientations to language planning. Journal of the National Association for Bilingual Education (NABE) 8(2): 15-34.

Sam, M. 2010. The development and implementation of computer literacy terminology in isiXhosa. MA thesis. Grahamstown: Rhodes University.

Stavans, A. and C. Hoffman. Multilingualism. Key topics in sociolinguistics. Cambridge: Cambridge University Press.

Stein, J. 2014. Higher education and the aesthetics of transformation: the changing face of Rhodes University, 1994-2014. MA thesis proposal. Grahamstown: Rhodes University.

Steyn, M. 2014. Africanisation and the higher education sector: Africanisation and the transformation of university culture. Paper presented at the Rhodes University Seminar on Africanisation and Higher Education. Grahamstown.

Ting-Toomey, S. 1999. Communicating across cultures. New York. London: The Guilford Press.

Turner, N. 2011. African languages, compulsory in tertiary institutions at South African universities, illusory initiative or inspired interventionism. ALASA Conference Paper. Durban: UKZN.

Use of Official Languages Act, Act 12 of 2012.

Webb, A. 2006. Moving towards an African identity: A personal vision for the future of Rhodes University. Unpublished inaugural address. Grahamstown: Rhodes University.

Wildsmith-Cromarty, R. 2010. The development of a sustainability model for the integration and use of an African language as a language of learning and teaching in higher education. Alternation 17(1): 27-48.

Wolff, E. 2002. The heart of the African question in education. In F. Owino (ed.) Speaking African, African languages for education and development. Rondebosch, Cape Town: Centre for Advanced Studies in African Societies.

Wolff, E. 2013. Multilingualism and language policies in Africa, with particular reference to language-in-education issues. In C. Altmayer and E. Wolff (eds.) Africa: Challenges of multilingualism. Frankfurt: Peter Lang. pp. 11-33. 